OPEN ACCESS

Citation: B. Yuksel, O. Aksoy, M. Karatas (2021) The cytological and molecular investigation of the toxic effects of the herbicide Roundup on Cucumis sativus. Caryologia 74(1): 3-12. doi: 10.36253/caryologia-951

Received: May 25, 2020

Accepted: October 16, 2020

Published: July 20, 2021

Copyright: (c) 2021 B. Yuksel, O. Aksoy, M. Karatas. This is an open access, peer-reviewed article published by Firenze University Press (http://www. fupress.com/caryologia) and distributed under the terms of the Creative Commons Attribution License, which permits unrestricted use, distribution, and reproduction in any medium, provided the original author and source are credited.

Data Availability Statement: All relevant data are within the paper and its Supporting Information files.

Competing Interests: The Author(s) declare(s) no conflict of interest.

\section{The cytological and molecular investigation of the toxic effects of the herbicide Roundup on Cucumis sativus}

\author{
Burcu Yuksel ${ }^{1, *}$, Ozlem Aksoy ${ }^{2}$, Melis Karatas $^{2}$ \\ ${ }^{1}$ Vocational School of Kocaeli Health Services, Kocaeli University, Kocaeli, Turkey \\ ${ }^{2}$ Department of Biology, Faculty of Letters and Sciences, Kocaeli University, Kocaeli, Turkey \\ *Corresponding author. E-mail: burcu.yuksel@yahoo.com
}

\begin{abstract}
In the current study, it is aimed to investigate the toxic effects of a widely used herbicide Roundup containing active ingredient glyphosate on cucumber (Cucumis sativus) by cytological and molecular investigation. Three different concentrations $(0.6 \%, 1.2 \%$ and $2.4 \%)$ of Roundup were applied to cucumber for 48 and 72 hours. At the end of the application procedure, the germination percentage, mean root length, mitotic frequency and mitotic abnormalities, RAPD profiles and Genomic template stability (GTS) were determined in root apical meristematic cells. For RAPD PCR analysis 10 RAPD primers were used, 8 of them produced band patterns and it was found that 5 RAPD primers among them produced unique polymorphic band patterns and subsequently were used to produce a total of 24 bands. Observed percentage of polymorphism was $26 \%$. The changes in RAPD profiles after Roundup treatment was included variations as gain and/or loss of bands compared with the control group. Genomic template stability changed in RAPD profiles at various Roundup concentrations.
\end{abstract}

Keywords: Cucumis sativus, RAPD PCR, root growth, genotoxicity, glyphosate.

\section{INTRODUCTION}

Recent in vivo and in vitro experiments have been reported the impact of chemical groups of pesticides as they are regarded a significant set of environmental pollutants (Khan 2016; Lushchak et al. 2018; Alvarez et al. 2017). Pesticides are classified into different groups such as organophosphates, organochlorines, carbamates and pyrethroids (Vakonaki et al. 2013). Nevertheless, previous findings about the genotoxicity of the most of the pesticides are rare and the findings of the different studies are inconsistent (Sarath et al. 2019). Roundup includes the glyphosate [N- (phosphonomethyl)glycine] as the active ingredient, and is a well-known and popular brand name of a universal, broad-spectrum herbicide manufactured in U.S. It is the top selling herbicide in the world at least for 40 years, as well (Ho and Cummins 2010). The main ingredient of the Roundup, the glyphosate, destroys the organisms it targets by inhibiting the enzyme, 5-enolpyruvoyl-shikimate3-phosphate 
synthetase (EPSPS), which is a vital source for the development of popular aromatic amino acids including phenylalanine, tyrosine and tryptophan (Schaumburg et al. 2016).

The chief beneficiaries and application areas of pesticides are plants, sometimes they themselves are the target organism as in the case of weeds and sometimes they carry hazardous targets on them such as pests, insects and pathogenic fungi, etc. Sources of exposure include the direct application or via soil and water as well as atmospheric drift. Pesticides enter reaction with various nucleophilic centers of cellular biomolecules, including DNA because of their reactivity and electrophilic behaviours (Benedetti et al. 2018; Bolognesi 2003). They can also create other more volatile electrophilic products that can either transform cellular components or are digested to some other steadier products. Control and treatment group design studies, qualitatively and quantitative, can elicit the effects of genotoxicity of the pesticides. In the studies that use RAPD method, the previous research utilized diagnostic analysis by examining the change in band intensity or disappearance and/or appearance of RAPD bands, and the phenetic numerical analysis that would give us ideas about the general genetic mixture of populations, which is also labelled as the genetic similarity analysis (Lynch and Milligan 1990; De Wolf et al. 2004).

Glyphosate is usually used in two ways: it can be put on foliage or added to freshly cut stumps. It works by progressing through the plant to its actively growing areas and inhibiting protein synthesis. Similar in chemical structure to an amino acid, glyphosate prevents plants from creating three amino acids required for growth (Poletta et al. 2009). Thus it is aimed to investigate the toxic effects of a widely used herbicide Roundup containing active ingredient glyphosate on cucumber (Cucumis sativus) by cytological and molecular studies, which has not been done before. The use of parameters such as germination and root growth to assess the toxicity of various substances is rapidly increasing, as data on germination can inform us about the lethal effects of the herbicides used. Delay in germination or root growth can provide information about non-lethal but metabolic activity.

\section{MATERIAL AND METHODS}

\section{Determination of EC50}

We used 6 different concentrations of the herbicide Roundup including the suggested concentration to find out the EC50 (effective concentration that lower the root length $50 \%$ of the control). After $48^{\text {th }}$ and $72^{\text {th }}$ hour, for each concentration, the mean value of 100 roots was extracted as a percent of the control value. Then, the obtained result was utilized to determine the EC50 value.

\section{Cytological Experiments}

Cytological response was observed in the root apical meristem of. The root tips were placed in a solution of Carnoy with the following concentration of 3:1, alcohol: acetic acid, and hydrolyzed in $1 \mathrm{~N} \mathrm{HCl}$ at $60^{\circ} \mathrm{C}$ for approximately 5-10 minutes and then were crushed in a $2 \%$ orcein stain in $45 \%$ acetic acid. Slides of the cucumber were stored in a freezer and scrutinized 30 days later (Rank and Nielsen 1994).

\section{Mitotic analysis.}

Mitotic index was calculated by counting at least 1000 cells from each of the paste preparations (Equation 1). The percentage mitotic index was determined by dividing the number of cells divided by the total number of cells and multiplying by 100 ;

Mitotic index $(\%)=($ Number of Divided Cells $) /$

(Total number of cells) X100

Detection of mitotic abnormality percentage and frequencies

The chromosomal abnormalities and cellular anomalies determined at each division stage were determined and divided by the number of normal cells, and mitotic abnormality percentage and frequencies were calculated (Equation 2).Chromosomal abnormalities were evaluated separately in all phases of mitosis and photographic data was obtained using an Olympus BX51 photomicroscope. Three replicates were prepared for each concentration.

Mitotic abnormality percentage $=($ Chromosomal abnormalities and cellular anomalies)/(Number of Divided Cells Total number of cells) X100

\section{Germination percentage and root length values}

In our study, as a result of the treatment of C. sativus seeds treated for 48 and 72 hours with different concentrations of Roundup $(0.05 \%, 0.1 \%, 0.5 \%, 1 \%, 1.2 \%$, $2 \%)$, the change in germination percentage and differ- 
ences in root lengths were determined. All experiments were carried out in triplicate.

\section{RAPD PCR Analysis}

A Qiagen DNeasy Plant Mini Kit was utilized to express genomic DNA from 0.1-0.2 g powdered root tissue. The spectrophotometer Shimadzu UV-mini 1240 was used to assess and calculate the quantity and quality of DNA. A commercial set of 10 random 10-mer primers was obtained (Thermo Scientific). PCR amplifications were carried out in a $25 \mu L$ reaction mixture with $10 \mathrm{ng}$ of template DNA, $1 \mathrm{X}$ Taq polymerase buffer and 1 $\mathrm{U}$ of Taq polymerase, and $2.5 \mathrm{mM} \mathrm{MgCl} 2,1 \mu \mathrm{M} \mathrm{dNTP}$, $1 \mathrm{mM}$ primer. Amplifications were done in a TC-3000 Thermal Cycler. The cycle programmed was made up of a preliminary denaturation step at $94^{\circ} \mathrm{C}$ for $5 \mathrm{~min}$, followed by 40 cycles of $94^{\circ} \mathrm{C}$ for $1 \mathrm{~min}, 30^{\circ} \mathrm{C}$ for $1 \mathrm{~min}$, $72^{\circ} \mathrm{C}$ for $1 \mathrm{~min}$, and a final elongation at $72^{\circ} \mathrm{C}$ for 5 min. The PCR products were kept on a $1 \%$ agarose gel with ethidium bromide $(0.5 \mu \mathrm{g} / \mathrm{mL})$ and all digital photographs were taken by the UVP GelDoc-It 310 Imaging System. A $1 \mathrm{~kb}$ DNA ladder was used as size marker (Fermentas). 10-mer oligonucleotide primers of $60-70 \%$ GC content were benefitted from during the monitoring C. sativus genome for the modification. A negative control with no DNA template was also performed in each PCR amplification to validate the absence of any contamination.

\section{Estimation of genomic template stability}

The genomic template stability (GTS) was determined as follows: GST\% $=(1-\mathrm{a} / \mathrm{n})$ X 100. This reads as where (a) RAPD polymorphic profiles found in each treated sample and $(\mathrm{n})$ the number of total bands in the control (Atienzar et al. 1999; Liu et al. 2007). Polymorphism detected in RAPD profiles comprised of disappearance of a normal band and appearance of a new band compared to the control RAPD profiles (Atienzar et al. 2002). The average was later computed for each experimental group that were treated with various Roundup concentrations.

\section{Data Analysis}

Because of the dominant characteristics of RAPD markers, each band was acknowledged as a representative of the phenotype at a single biallelic locus. A binary matrix consisting of present (1) or absent (0) was created by marking each amplified fragment from each individual. In the marking, only pure and different bands were counted. Bands with the same gel mobilities were taken as homologous. The matrix was used to create an input file and evaluated with the software program POPGENE 1.32 (Nei 1978).

\section{RESULTS}

Genotoxic characteristics of the pesticide Roundup in C.sativus root tip cells were examined in this study. Because of its popularity in everyday use in the field of agriculture, a commercial form of the pesticide was examined. C.sativus was utilized as the test system due to its usage on plants in agriculture and plants might yield exceptional genotoxic metabolites. The EC50 value of Roundup was calculated as $1.2 \% \mathrm{ml} / \mathrm{L}$ and we treated the root tips were with the concentrations of $0.6 \%$ (EC50/2), 1.2\% (EC50), and 2.4\% (2xEC50) $\mathrm{ml} / \mathrm{L}$ as shown in Figure 1.

Figure 2 shows that the root lengths are reduced by half with the EC50 concentration of $1.2 \%$ Roundup treatment.

Table 1 shows as a result of the treatment of C.sativus seeds with Roundup different concentrations, it was observed that the germination percentage, which was $100 \%$ after 72 hours in the control group, decreased

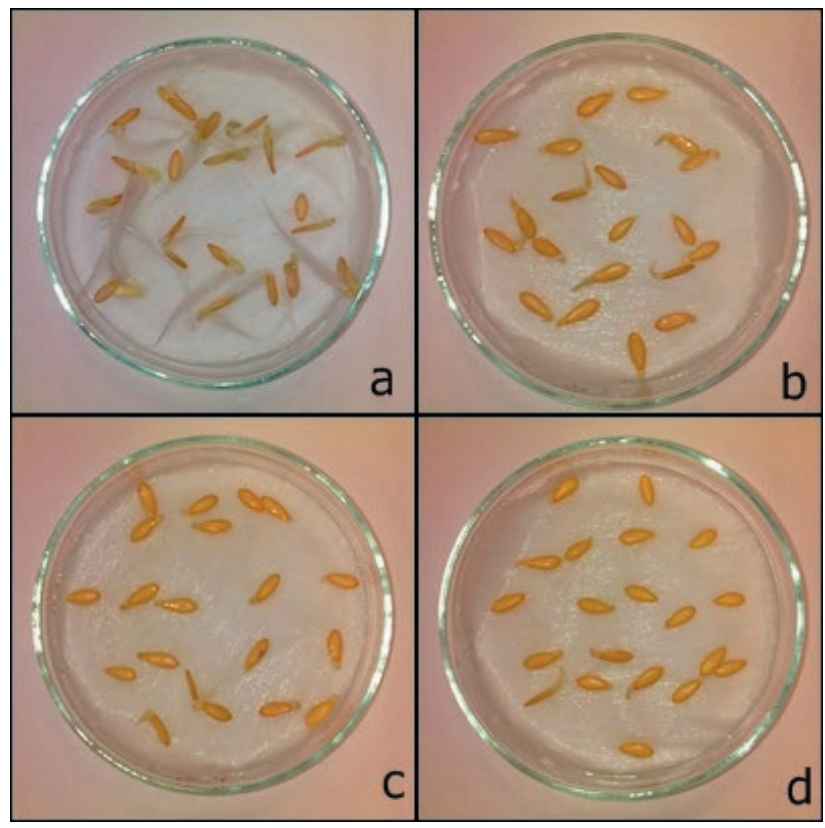

Figure 1. C.sativus seeds treated with Roundup concentrations a) control, b) $0.6 \%$, c) $1.2 \%$, d) $2.4 \%$. 


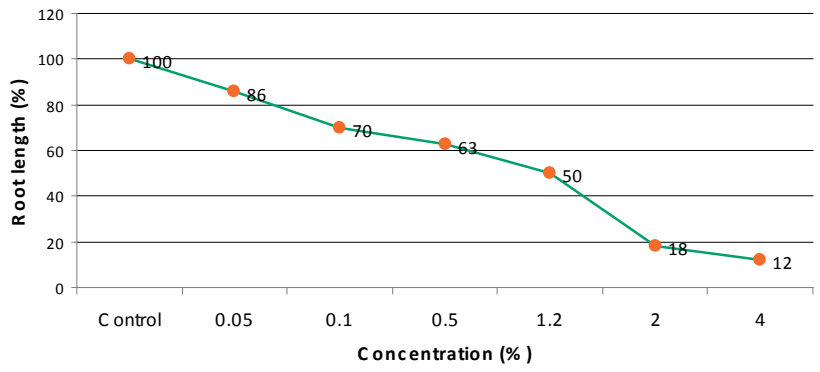

Figure 2. Root length percentages in C.sativus treated with Roundup showing EC50 value $\left(72^{\text {th }} \mathrm{h}\right)$.

Table 1. The mean of determined values of the germination percentages in $48^{\text {th }}$ and $72^{\text {th }}$ hour.

\begin{tabular}{lcc}
\hline \multirow{2}{*}{$\begin{array}{l}\text { Roundup } \\
\text { Concentration (\%) }\end{array}$} & \multicolumn{2}{c}{ Germination percentage means } \\
\cline { 2 - 3 } & $48^{\text {th }}$ hour & $72^{\text {th }}$ hour \\
\hline control & 100 & 100 \\
0.05 & 97.5 & 100 \\
0.1 & 95 & 95 \\
0.5 & 90 & 90 \\
1 & 87.5 & 92.5 \\
1.2 & 30 & 77.5 \\
2 & 57.5 & 87.5 \\
4 & 45 & 60 \\
\hline
\end{tabular}

in parallel with the Roundup concentration increase, respectively.

Results of the study revealed that Roundup modified the mitotic cycle and reduced the mitotic index in C.sativus root tip cells. A significant decrease was observed in all concentrations compared to the control (Table 2). The mitotic index in the control group was 26.7, and 8.5, 5.2 and 1.7 at $0.6 \%, 1.2 \%$ and $2.4 \%$ Roundup concentrations, respectively. It was also observed that the amount of the dose had effects on the reduction of the mitotic at index, which were all significant at different concentrations according to $\mathrm{P}<.005$. These
Table 2. The effect of Roundup concentrations on mitotic index.

\begin{tabular}{lcccc}
\hline $\begin{array}{l}\text { Roundup } \\
\text { Concentration } \\
\%\end{array}$ & $\begin{array}{c}\text { The number } \\
\text { of divided } \\
\text { cells }\end{array}$ & $\begin{array}{c}\text { Mitotic } \\
\text { Index } \\
(\%) \pm \text { SD }\end{array}$ & $\begin{array}{c}\text { Standard } \\
\text { ERROR }\end{array}$ & P Value \\
\hline Control & 267 & $26.7 \pm 1.117$ & .22 & - \\
0.6 & 85 & $8.5 \pm .812$ & .11 & $.000^{*}$ \\
1.2 & 52 & $5.2 \pm .652$ & .08 & $.000^{*}$ \\
2.4 & 17 & $1.7 \pm .213$ & .02 & $.000^{*}$ \\
\hline
\end{tabular}

${ }^{*} \mathrm{P}<.005$

results demonstrated that concentrations of Roundup were cytotoxic in cucumber. Previous literature reported similar results in mitosis from the treatment of the herbicides racer (Yuzbaşığlu et al. 2003), atrazine (Bolle et al. 2004), and arsenal (Grisolia et al. 2004). This might stem from some potential mechanisms for chemically reduced mitotic index in plant cells. Firstly, the reduction in the Mitotic Index can be caused because of the blocking of G1 suppressing DNA synthesis (Shcneiderman et al. 1971). The second potential reason might be a hinderance of G2 which blocks the cell from ingoing mitosis. The reduction in the mitotic index could be a result of the inhibition of DNA synthesis at the S-phase (Sudhakar et al. 2001).

We also examined the mitotic abnormality percentages and frequencies for prophase, metaphase, anaphase and telophase for different concentrations at different hours (Table 3). We observed that mitotic abnormality increased for all measurements as the concentration amount increased. Compared to the control group, the highest percentage of abnormal dividing cells was observed at $2.4 \%$ Roundup concentration metaphase (300) and 1.2\% Roundup concentration in telophase (300) stage.Later, $2.4 \%$ Roundup concentration was determined in prophase (209), at $0.6 \%$ in metaphase (144) and at $1.2 \%$ in prophase (140). These data show that increasing coumarin concentrations increase the amount of abnormal dividing cells in each division phase. Abnormal and normal cells were not observed

Table 3. The effect of Roundup concentrations on the mitotic abnormality percentage and frequencies.(N: Normal dividing divider, A; abnormal dividing cells, \%; percentage data).

\begin{tabular}{|c|c|c|c|c|c|c|c|c|c|c|c|c|}
\hline \multirow{2}{*}{ Concentrations - } & \multicolumn{3}{|c|}{ Prophase } & \multicolumn{3}{|c|}{ Metaphase } & \multicolumn{3}{|c|}{ Anaphase } & \multicolumn{3}{|c|}{ Telophase } \\
\hline & $\mathrm{N}$ & A & $\%$ & $\mathrm{~N}$ & $\mathrm{~A}$ & $\%$ & $\mathrm{~N}$ & A & $\%$ & $\mathrm{~N}$ & A & $\%$ \\
\hline control & 66 & 18 & 27.2 & 19 & 5 & 26 & 11 & 3 & 27 & 7 & 1 & 14 \\
\hline $0.6 \%$ & 50 & 27 & 54 & 9 & 13 & 144 & 8 & 5 & 62 & 3 & 2 & 66 \\
\hline $1.2 \%$ & 30 & 42 & 140 & 10 & 13 & 130 & 8 & 6 & 75 & 1 & 3 & 300 \\
\hline $2.4 \%$ & 11 & 23 & 209 & 3 & 9 & 300 & 3 & 4 & 133 & - & - & - \\
\hline
\end{tabular}




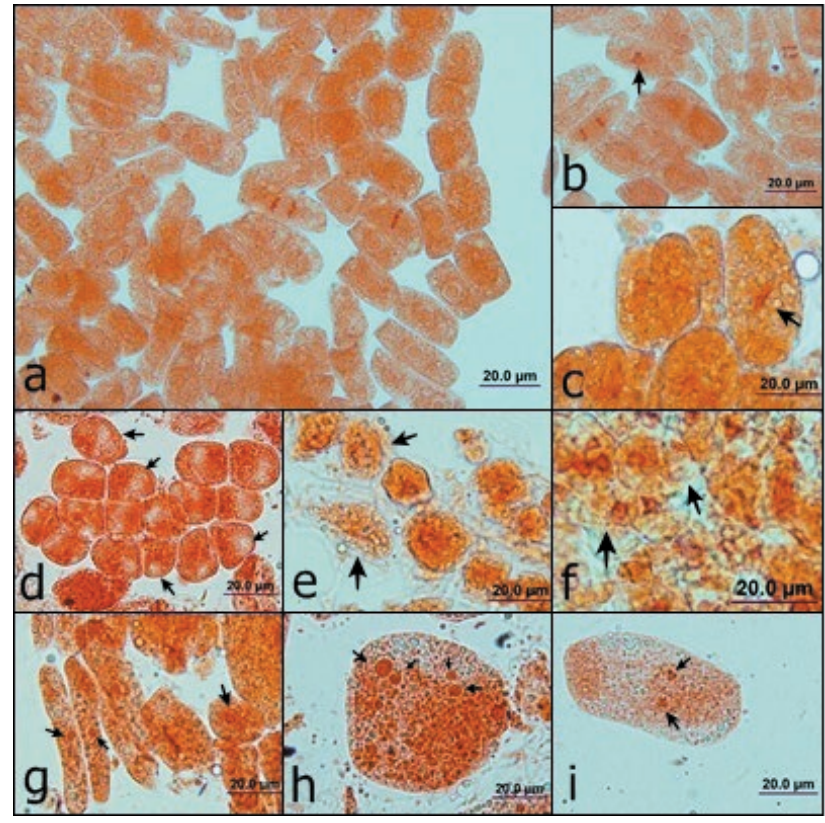

Figure 3. C.sativus root tip cells treated with Roundup concentrations a) control, b) stickiness, c) shift in the equatorial plane of metaphase, d) vacuolization, e) and f) nuclei degeneration, g), h) and i) micronuclei formation.

at a concentration of $2.4 \%$, possibly due to the failure of the telophase phase (Table 3).

Roundup boosted the percentage of abnormal cells in C.sativus. This growth was significant in all concentrations in comparison to the control and the amount of the dose was also a contributing factor. The abnormalities that were commonly observed were stickiness in chromosomes, nuclei degeneration, micronuclei formation and vacuolization in cytoplasm (Figure 3).

After Roundup treatment, genomic DNA profiles and genomic DNA quantities and purities were shown in Figure 4. By evaluating the agarose gel images, it was decided that the DNA belonging to the control group and Roundup groups were sufficient and purity for RAPD-PCR experiments.

The list of polymorphic and monomorphic RAPD primers (Table 4), the number of primers compared between $0.6 \%, 1.2 \%$ and $2.4 \%$ treatments of Roundup and the percentage of polymorphism for all primers (Fig. 5) were determined.

10 -mer oligonucleotide primers of $60-70 \%$ GC content were benefitted from during the monitoring $C$. sativus genome for the modification, but among all, only eight primers produced precise and steady results. The total number of bands was 26 for untreated control treatments and 70 for all treatments ranging from 258 to

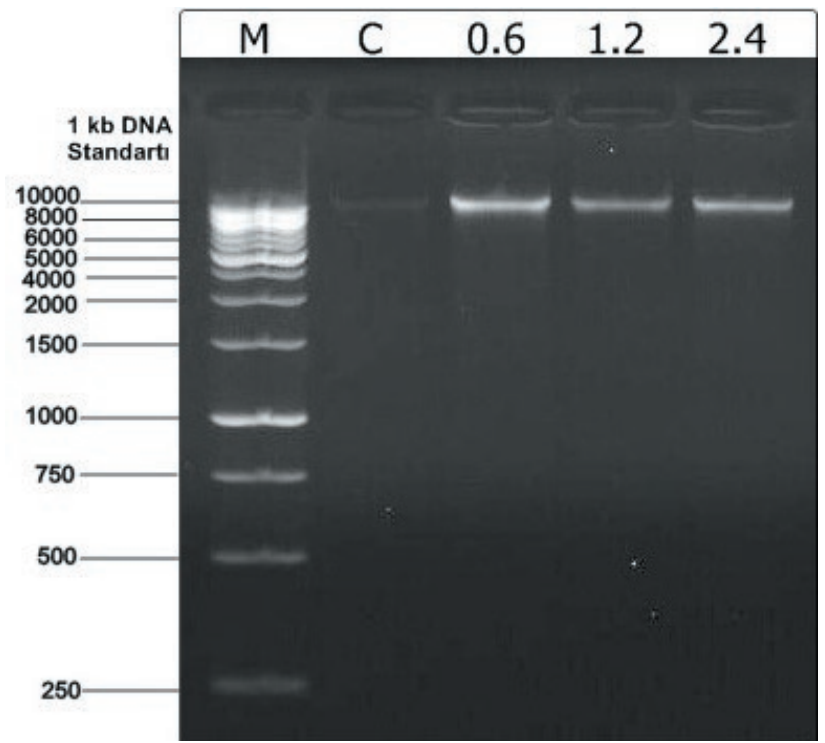

Figure 4. Genomic DNA profiles of cucumber exposed to untreated control (C), $0.6 \%(0.6), 1.2 \%$ (1.2) and 2.4\% treatments of Roundup.

Table 4. The list of polymorphic and monomorphic RAPD primers compared to $0.6 \%, 1.2 \%$ and $2.4 \%$ treatments of Roundup.

\begin{tabular}{|c|c|c|}
\hline Concentration(\%) & Ionomorphic primers & Polymorphic primers \\
\hline 0.6 & OPU-6 & $\begin{array}{l}\text { OPC-5, OPC-6, OPU-7, } \\
\text { OPC-8, OPC-9, OPU-3 }\end{array}$ \\
\hline 1.2 & OPU-6, OPU-3 & $\begin{array}{l}\text { OPC-5, OPC-6, OPU-7, } \\
\text { OPC-8, OPC-9, OPU-2 }\end{array}$ \\
\hline 2.4 & OPU-6,OPU-3 & $\begin{array}{l}\text { OPC-5, OPC-6, OPU-7, } \\
\text { OPC-8, OPC-9, OPU-5 }\end{array}$ \\
\hline
\end{tabular}

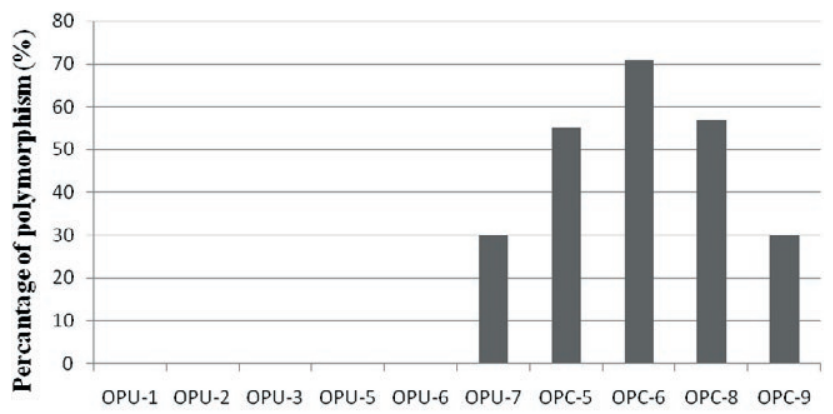

Primers

Figure 5. The percentage of polymorphism for all primers in Roundup treated cucumber

$1170 \mathrm{pb}$. One primer generated the same RAPD profiles for the roots (Figure 6).

Conversely, 8 RAPD profiles demonstrated important alterations between untreated control and treated 


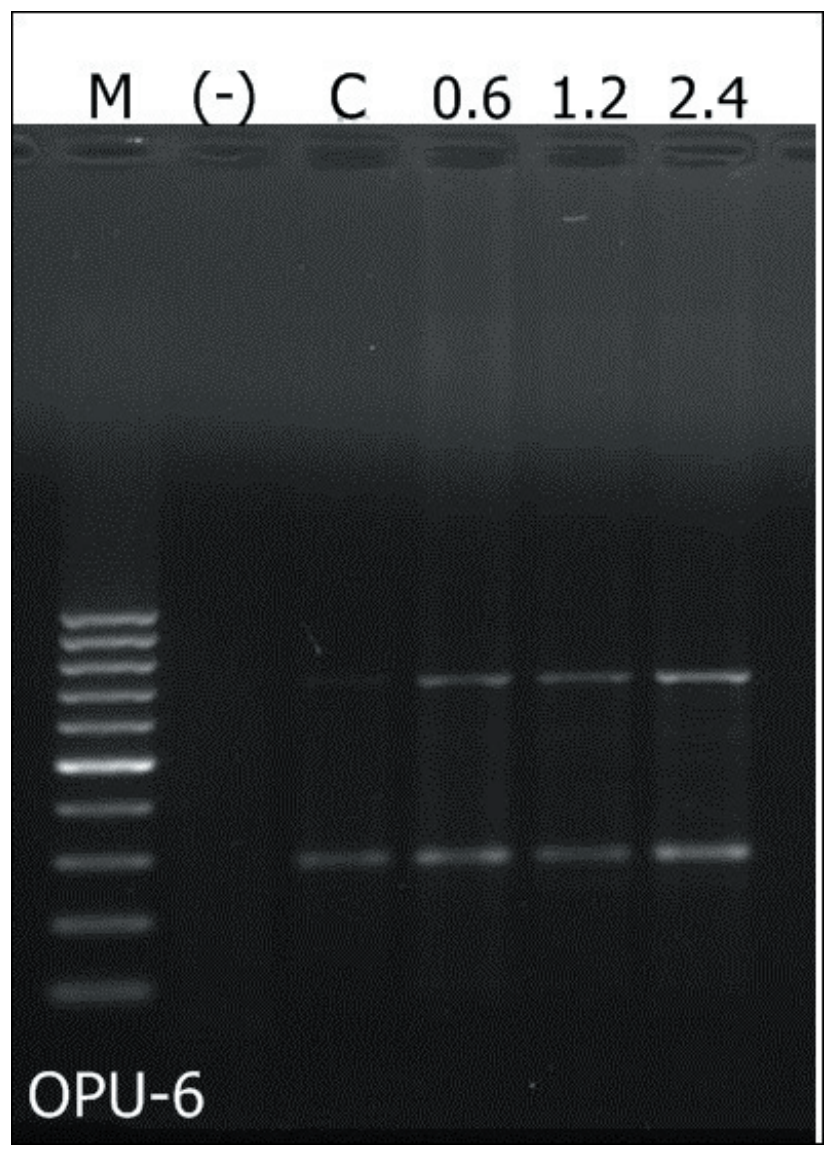

Figure 6. Monomorphic RAPD profile of cucumber exposed to untreated control (C), $0.6 \%(0.6), 1.2 \%(1.2)$ and $2.4 \%(2.4)$ treatments of Roundup. RAPD profiles were generated using primer OPU-6.

roots (Figure 7) with apparent alterations (disappearance and/or appearance) in the quantity and extent of amplified DNA fragments for various primers.

The modifications in RAPD profiles were reported for treated C. sativus when compared with their controls (Table 5). Polymorphic bands were perceived at some of the treatments for 8 primers. Polymorphisms were because of the appearance and disappearance of the amplified bands in the treated profiles when compared with control profiles. Value of polymorphisms P (\%) was observed at $26 \%$. On the other hand, value of polymorphisms P (\%) for Roundup treatments: $0.6 \%, 1.2 \%$ and $2.4 \% ; 41 . \%, 79 \%$ and $77 \%$, respectively. The genomic template stability (GTS, \%) values, which is a qualitative tool that measures modifications in RAPD profiles, was determined for each 8 primers and showed in Table 6. GTS values reduced at a significant amount in $0.6 \%$ Roundup concentration.
Table 5. Genomic template stability (GTS, \%) of C.sativus exposed to untreated control, $0.6 \%, 1.2 \%$ and $2.4 \%$ treatments of Roundup.

\begin{tabular}{lcccc}
\hline \multirow{2}{*}{ Primers } & \multicolumn{4}{c}{ Roundup Concentration (\%) } \\
\cline { 2 - 5 } & Control & 0.6 & 1.2 & 2.4 \\
\hline OPC-5 & 100 & 66 & 83 & 66 \\
OPC-6 & 100 & 0 & 0 & 0 \\
OPC-8 & 100 & 0 & 50 & 50 \\
OPC-9 & 100 & 66 & 100 & 100 \\
OPU-2 & 100 & 100 & 100 & 100 \\
OPU-3 & 100 & 0 & 100 & 100 \\
OPU-5 & 100 & 100 & 100 & 100 \\
OPU-7 & 100 & 0 & 100 & 100 \\
Average & 100 & 41 & 79 & 77 \\
\hline
\end{tabular}

Table 6. The number of bands in control and molecular sizes (base pair, bp) of disappearance (-) and/or appearance (+) of DNA bands for all primers in Roundup treated cucumber (Vision WorksLS image analyzer software).

\begin{tabular}{|c|c|c|c|c|c|}
\hline \multirow{2}{*}{\multicolumn{3}{|c|}{ Primers Control }} & \multicolumn{3}{|c|}{ Roundup Concentration (\%) } \\
\hline & & & 0.6 & 1.2 & 2.4 \\
\hline \multirow[t]{2}{*}{ OPC-5 } & 6 & + & $1223 ; 694$ & 1245 & 1245 \\
\hline & & - & $596 ; 314 ; 254$ & 0 & 0 \\
\hline \multirow[t]{2}{*}{ OPC-6 } & 2 & + & $651 ; 524$ & $651 ; 524 ; 915 ; 734$ & $651 ; 524 ; 915 ; 734$ \\
\hline & & - & 230 & 230 & 0 \\
\hline \multirow[t]{2}{*}{ OPC-8 } & 2 & + & $618 ; 430$ & 625 & 600 \\
\hline & & - & 477 & 477 & 477 \\
\hline \multirow[t]{2}{*}{ OPC-9 } & 3 & + & 504 & 0 & 0 \\
\hline & & - & 200 & $552 ; 350 ; 200$ & 200 \\
\hline \multirow[t]{2}{*}{ OPU-2 } & 3 & + & 0 & 0 & 0 \\
\hline & & - & 0 & 237 & 0 \\
\hline \multirow[t]{2}{*}{ OPU-3 } & 1 & + & $421 ; 228$ & 0 & 0 \\
\hline & & - & 0 & 262 & 262 \\
\hline \multirow[t]{2}{*}{ OPU-5 } & 4 & + & 0 & 0 & 0 \\
\hline & & - & 0 & 537 & $537 ; 795$ \\
\hline \multirow[t]{2}{*}{ OPU-7 } & 3 & + & $867 ; 528 ; 426$ & 0 & 0 \\
\hline & & - & 0 & 352 & 352 \\
\hline Total & 24 & & $12(+) ; 6(-)$ & $6(+) ; 9(-)$ & $7(+) ; 6(-)$ \\
\hline
\end{tabular}

RAPD profiles showed significant differences (loss of a normal band and / or formation of a new band) in the number and size of the replicated DNA bands between the control and treated C. sativus roots. These changes, which were determined in the RAPD profiles of the applied C. sativus roots, are given in Table 4 with all the details. The maximum band increase was seen in $1.2 \%$ and $2.4 \%$ Roundup applications of the OPC 6 primer. The maximum band change in total was observed in $0.6 \%$ Roundup application (Table 6). 


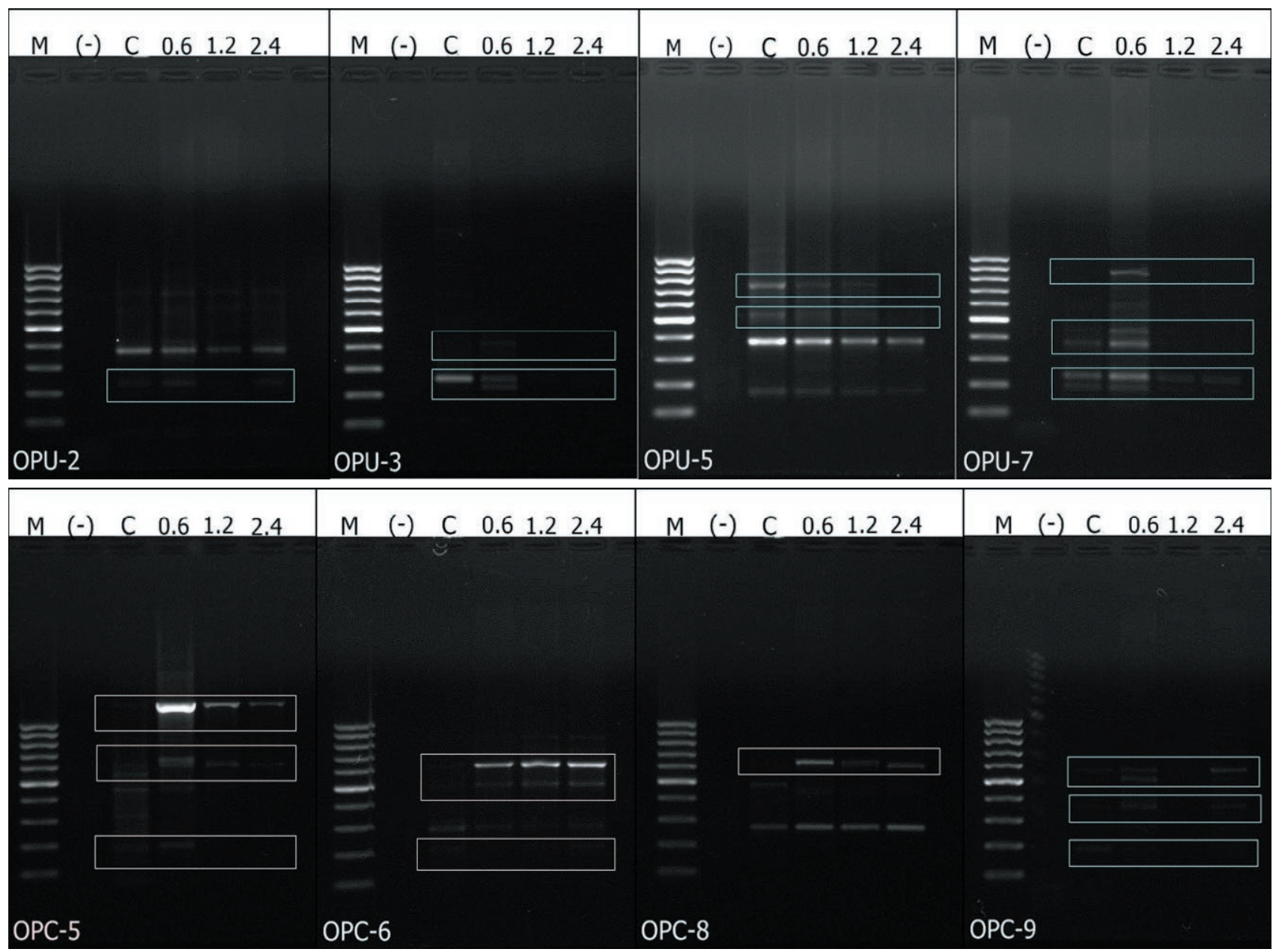

Figure 7. Polymorphic RAPD profiles of cucumber exposed to untreated control (C), $0.6 \%(0.6), 1.2 \%(1.2)$ and $2.4 \%(2.4)$ treatments of Roundup. RAPD profiles were generated using primer OPC-5, OPC-6, OPC-8, OPC-9, OPU-2, OPU-3, OPU-5 and OPU-7.

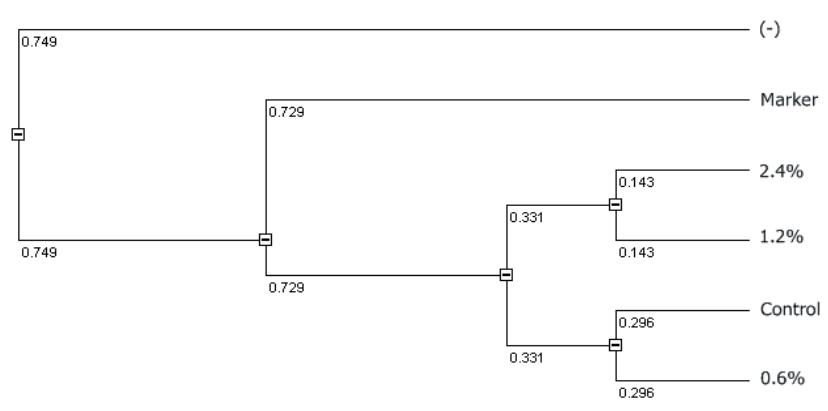

Figure 8. Dendrogram obtained by separate evaluation of protein band profiles which were obtained by SDS-PAGE in control group and Round up treated C. sativus roots.

The distance values between the dendrogram and the treatment groups obtained by separate evaluation of the protein band profiles obtained by SDS-PAGE in the control group and Roundup treated C. sativus roots were shown in figure 8. Roots treated and untreated in Dendrograms were composed of two main clusters. While $1.2 \%$ and $2.4 \%$ Roundup applications were on the same branch, control and $0.6 \%$ Roundup application were observed on the same branch.

\section{DISCUSSION}

The findings of this study demonstrated that the abnormalities were existent in stages of the mitosis in all treatments. The generation of mitotic abnormalities seems to be a usual impact of most chemicals (Shehata et al. 2011). The stickiness and disturbed stages were the most commonly observed abnormalities. Provided of chromosome loss are underdeveloped chromosome, stickness, multipolarity and c-mitosis. Substances that cause fractures in chromosomes may cause chromosome 
bridge formation or changes in chromosome structure (Yuksel 2017, Radic et al. 2010) Backward chromosomes; As a result of disturbances in the organization or functions of spindle yarns (Turkoglu 2012; Bonciu et al.2018). In our study, the first type of abnormalities was the stickiness discovered in most phases of mitosis following various Roundup treatments. The amount of sticky cells rose up in all stages of mitotic division as the Roundup concentration upsurged in the most of the treatments. Moreover, this characteristic was augmented via the extending of interval time from 24 to $48 \mathrm{~h}$ then reduced in the 10 days period interval in most treatments. The results of our study supported previous research, such as (Aksoy et al. 2008; Yuksel and Aksoy 2017; Bonciu 2018). Previous studies stated that the chromosome stickiness might stem from breakage and swap between chromatin fibers over adjoining chromosomes. Another form of abnormalities was the ill-formed, which was seen in metaphase and anaphase in the experiments, and the ratio of this characteristic did not depend on the Roundup concentration or period interval. This abnormality was found in previous research, for example Polit $e t$ al., 2003, Horak, et al., 2015 (Soybean) following many chemical treatments they claimed that the chromosomes disturbed might stem from the impact of the chemical treatment on proteins forming the spindle apparatus. The difference in the ratio between the number of histone and other proteins can increase the adhesiveness of the nuclear chromatin, which ensures optimal organization, usually causing the development of atypical metaphases and anaphasis, chromosomal bridges in the anaphase and telophase, and finally, inhibition of cytokinesis and the formation of binuclear cells can be observed. (Bonciu et al.2018). Laggard chromosomes were also seen in some Roundup treatments in metaphase anaphase and telophase (Frescura et al. 2013;Dimitrov et al. 2006). Laggard at metaphase could be caused by the crash of the spindle apparatus to manage and operate in a standard way (Haiba et al. 2011). Lastly, the emergence of these chromosomal abnormalities could be attributed to the mutagenic potential of Roundup. In another study, cytotoxic and genotoxic effects of cycloxidime and quizalofop-p-ethyl herbicides on Allium cepa were investigated, and it was observed that decreased mitotic index and chromosomal abnormalities were increased. Cycloxidime and quizalofop-p-ethyl concentrations increased, compared to the control group of cells with the chromosome stickiness, as the most common chromosomal aberration in the root tips of Allium cepa, where herbicide was applied. (Rosculete et al. 2018). Previous studies also found that adhesive chromosomes reflect highly toxic effects and possibly lead to cell death (Donghua et al. 1996). Genotoxicity is among the major side effects of pesticide exposure (Boumaza et al. 2016). With these results, we can conclude that Roundup has a toxic effect and reveals a cell death process with increased chromosomal anomalies. Long-term application of herbicides for control of harmful pathogens in agriculture can economically affect plants important to humans and endanger their genetic material. Herbicides should be safe, healthy and effective. Therefore, prior examination of the genotoxic, cytotoxic and biochemical impact of herbicides on plants and other systems is important for their application for agricultural uses.

In this study, RAPD was utilized to identify DNA mutilation in the roots of C.sativus and the value of polymorphisms $\mathrm{P}$ (\%) were increased with increasing Roundup concentration. On the other hand, GTS values decreased obviously in $0.6 \%$ Roundup concentration. Inhibition of shoot and root development and proliferation of $\mathrm{Hg}, \mathrm{B}, \mathrm{Cr}$ and $\mathrm{Zn}$ elements in the roots and leaves of bean were detected following an upsurge in the concentration. The amount of polymorphisms $\mathrm{P}(\%)$ was $50.4 \%$ and $28.0 \%$ for the roots and leaves, respectively following RAPD analysis. To sum up, findings of this study reinforce the notion that the RAPD analysis is a reliable technique for the discovery of DNA damage caused by environmental pollutants such as toxic chemicals (Cenkci et al. 2009). Similarly, the study conducted by Enan (2006) discovered that 22 novel fragments emerged and 43 disappeared due to utilizing 350 $\mathrm{mg} / \mathrm{l}$ heavy metals to inundate Phaseolus vulgaris. Less band appearance/disappearance was used during the application of $150 \mathrm{mg} / \mathrm{l}$. The disappearance of bands be related with to the existence of DNA photoproducts (like pyrimidine dimmers, 6-4 photoproducts), which can be a facilitator of inhibition or reduction (bypass event)of the polymerization of DNA in the PCR reactions (Donahue et al. 1994; Nelson et al. 1996). Nonetheless, new fragments can be augmented since some sites open up to the primer following structural modifications in the DNA (Pietrasanata et al. 2000; Enan, 2006). The reason of this process might be point mutations and/or large rearrangements of the DNA. A single point mutation within the primer site can cause dramatic modifications in RAPD patterns (Williams et al. 1990).

\section{CONCLUSION}

Most of the cytotoxic and molecular focused studies examine the effects of environmental pollutants affecting plants. Long-term use of pesticides in high amounts causes various problems in the cytological, biochemical 
and genetic mechanisms of plants. (Eto 2018, Abdollahi et al. 2004). In the results of these studies, it is very important in terms of determining the possible contaminating effects especially for humans. The results of this study, based on the data collected by examining the cytotoxic and genotoxic effects of Roundup pesticide on C. sativus, show that Roundup may have some toxic effects. This work will motivate further research to examine the effects of cytological and genetic changes caused by pesticides used in plant development and growth. In addition, we believe that Roundup may have negative consequences for human health and the environment.

\section{REFERENCES}

Abdollahi M, Ranjbar A, Shadnia S, Nikfar S, Rezaiee A. 2004. Pesticides and oxidative stress: a review. Medical Sci. Mon. 10(6):141-147.

Aksoy O. 2008. Mitotic Change in Root Meristems of Lens culinaris Treated with Fusilade (fluazifop-pbutyl). Asian Journal of Cell Biol. 3:34-40.

Alvarez A, Saez JM, Costa JSD, Colin VL, Fuentes MS, Cuozzo SA, Amoroso MJ. 2017. Actinobacteria: current research and perspectives for bioremediation of pesticides and heavy metals. Chemosphere.166:41-62.

Atienzar FA, Venier P, Jha AN, Depledge MH. 2002. Evaluation of the random amplified polymorphic DNA (RAPD) assay for the detection of DNA damage and mutations. Mutation Res./Genetic Toxicology and Environmental Mutagenesis. 521(1-2):151-163.

Atienzar FA, Conradi M, Evenden AJ, Jha AN, Depledge MH. 1999. Qualitative assessment of genotoxicity using random amplified polymorphic DNA: comparison of genomic template stability with key fitness parameters in Daphnia magna exposed to benzo [a] pyrene. Environmental Tox. and Chem. 18(10):22752282.

Benedetti D, Lopes AB, De Souza CT, Ferraz DJ, Niekraszewicz L, Cappetta M, Da Silva J. 2018. DNA damage and epigenetic alteration in soybean farmers exposed to complex mixture of pesticides. Mutagenesis. 33(1):87-95.

Bolle P, Mastrangelo S, Tucci P. 2004.Clastogenicity of atrazine assessed with the Allium cepa test. Environ Mol Mutagen 43:137-141,

Bonciu E, Firbas P, Fontanetti CS, Wusheng J. 2018. An evaluation for the standardization of the Allium cepa test as cytotoxicity and genotoxicity assay. Caryologia, 71(3):191-209

Boumaza A, Lalaoui K, Khallef M, Sbayou H, Talbi H,
Hilali A. 2016. Assessment of Cytotoxic and Genotoxic Effects of Clodinafop-propargyl Commercial Formulation on Allium cepa L. J. Mater. Environ. Sci. 7:1245-1251

Bolognesi C. 2003. Genotoxicity of pesticides: a review of human biomonitoring studies. Mutation Res./ Reviews in Mutation Res., 543(3):251-272.

Cenkci S, Ylldız M, Ciğerci I, Konuk M, Bozdağ M. 2009. Toxic chemicals-induced gentoxicity detected by random amplified polymorphic DNA (RAPD) in bean (Phaseolus vulgaris L.) seedlings. Chemosphere. 76:900-906.

De Wolf H, Blust R, Backeljau T. 2004. The use of RAPD in ecotoxicology. Mutation Res./Reviews in Mutation Res., 566(3):249-262.

Dimitrov BD, Gadeva PG, Benova DK, Bineva MV. 2006. Comparative genotoxicity of the herbicides Roundup, Stomp and Reglone in plant and mammalian test systems. Mutagenesis. 21(6):375-382.

Donahue BA, Yin S, Taylor JS, Reines D, Hanawalt PC. 1994. Transcript cleavage by RNA polymerase II arrested by a cyclobutane pyrimidine dimer in the DNA template. Proc Natl Acad Sci USA 91(18):85028506.

Donghua L, Wusheng J, Chunli W. 1996. Effects of $\mathrm{Zn}^{2+}$ on root growth, cell division and nucleolus of Allium cepa L. J. Environ. Sci. 8:21-25

Enan MR. 2006. Application of random amplified polymorphic DNA (RAPD) to detect the genotoxic effect of heavy metals. Biotechnol Appl Biochem 43:147-154.

Eto, M. 2018. Organophosphorus pesticides. CRC press.

Frescura VDS, Kuhn AW, Iv HDL, Paranhos JT, Tedesco SB. 2013. Post-treatment with plant extracts used in Brazilian folk medicine caused a partial reversal of the antiproliferative effect of glyphosate in the Allium cepa test. Biocell, 37(2):23.

Grisolia CK, Bilich MR, Formigli LM. 2004. A comparative toxicologic and genotoxic study of the herbicide arsenal, its active ingredient imazapyr, and the surfactant nonylphenol ethoxylate. Ecotox Environ Safety $59: 123-126$,

Haiba AA, Abd-El-Hamid NR, Abd-El-Hady EA, AlAnsary AEMF. 2011. Cytogenetic effect of insecticide Telliton and fungicide Dithane M-45 on meiotic cells and seed storage proteins of Vicia faba. The Jour. of American Sci., 7(1):19-25.

Ho MW and Cummins J. 2010. Glyphosate toxic \& Roundup worse, Available:http://www. percyschmeiser.com/Toxic.html

Khan SU .2016. Pesticides in the soil environment. Elsevier.

Liu L, Liu G, Gong Y, Dai W, Wang Y, Yu F, Ren Y. 2007. 
Evaluation of genetic purity of F1 hybrid seeds in cabbage with RAPD, ISSR, SRAP, and SSR markers. Hortsci., 42(3):724-727.

Lushchak VI, Matviishyn TM, Husak VV, Storey JM, Storey KB. 2018. Pesticide toxicity: a mechanistic approach. EXCLI jour., 17:1101.

Lynch M, Milligan BG. 1994. Analysis of population genetic structure with RAPD markers. Molecular ecol.. 3(2):91-99.

Nei M. 1978. Estimation of average heterozygosity and genetic distance from a small number of individuals. Gen., 89(3):583-590.

Nelson JR, Lawrence CW, Hinkle DC. 1996. Thyminethymine dimmer bypass by yeast DNA polymerase. Science 272:1646-1649.

Piesova E (2005). The effect of glyphosate on the frequency of micronuclei in bovine lymphocytes in vitro. Acta Veterinaria - Beograd. 55:101-109.

Pietrasanata LI, Smith BL, MacLeod MC. 2000. A novel apprach for analyzing the structure of DNA modified by benzo[a]pyrine diol epoxide at single-molecule resolution. Chem Res Toxicol 13:351-355.

Poletta GL, Larriera A, Kleinsorge E, Mudry MD. 2009. Genotoxicity of the herbicide formulation Roundup (glyphosate) in broad-snouted caiman (Caiman latirostris) evidenced by the Comet assay and the Micronucleus test. Mutat. Res./Gen. Toxic. and Envir. Mutag. 672(2):95-102.

Rank J, Nielsen MH. 1994. Evaluation of the Allium anaphase telophase test in relation to genotoxicity screening of industrial wastewater. Mutat. Res. 312:17-24.

Radic S, Stipanicev D, Cvjetko P, Mikelic IL, Rajcic MM, Sirac S, Pevalek KB., Pavlica P. 2010. Ecotoxicological assessment of industrial effluent using duckweed (Lemna minor L.) as a test organism, Ecotoxicology, 16:216-222.

Rosculete CA, Bonciu E, Rosculete E, Olaru LA. 2018. Determination of the Environmental Pollution Potential of Some Herbicides by the Assessment of Cytotoxic and Genotoxic Effects on Allium cepa. Int J Environ Res Public Health. 16(1):75. Published Dec 28. doi:10.3390/ijerph 16010075

Sanders HO. 2010.Toxicity of pesticides to the crustacean Gammarus lacustris. Technical papers of the bureau of sport fisheries and wildlife, No. 25. US Dept. of Interior Fish and Wildlife Service, Washington D.C

Sarath CC, Thomas S, Unni MR. 2019. Pesticides: Classification, Detection, and Degradation. Organic Farming: New Adv. Towards Sustainable Agricul. Sys. 71.

Schaumburg LG, Siroski PA, Poletta GL, Mudry MD. 2016. Genotoxicity induced by Roundup (Glyphosate) in tegu lizard (Salvator merianae) embryos. Pes- tic. biochem. and phys. 130:71-78.

Shcneiderman MH, Dewey WC, Highfield DP. 1971.Inhibition of DNA synthesis in synchronized Chinese hamster cell treated in G1 with cycloheximide. Exp Cell Res 67:147-155.

Sudhakar R, Ninge GKN, Venu G. 2001Mitotic abnormalities induced by silk dyeing industry effluents in the cell of Allium cepa. Cytologia 66:235-239.

Turkoglu Ş. 2012. Determination of genotoxic effects of chlorfenvinphos and fenbuconazole in Allium cepa root cells by mitotic activity, chromosome aberration, DNA content, and comet assay, Pestic. Biochem. Phys. 103:224-230.

Williams J, Kubelik AR, Livak KJ, Rafalski JA, Tinger SV. 1990. DNA polymorphisms amplified by arbitrary primers are useful as genetic markers. Nucleic Acid Res 18:6531-6535.

Vakonaki E, Androutsopoulos VP, Liesivuori J, Tsatsakis AM, Spandidos DA. 2013. Pesticides and oncogenic modulation. Toxicology, 307:42-45.

Yuksel B and Aksoy O. 2017. Cytological effects of coumarin on the mitosis of Lens culinaris Medik. Fresenius Environ. Bull., 26:6400-6407.

Yuksel B. 2017. Determination of Cytotoxic, B1ochemical, and Genotoxic Effects of Coumarin on Lentil (Lens Culınarts Medic). Doctoral desertation. Kocaelı Ünıversity.

Yuzbaşıŏlu D, Unal F, Sancak C. 2003.Cytological effects of the herbicide racer "flurochloridone" on Allium cepa. Caryologia 56:97-105. 